The basic structure of the mathematical 'language' 'Algol' was explained and developed to the state in which a complete problem was coded for illustration.

The discussion was opened by Dr. A. D. Booth, of Birkbeck College, London, who, after commenting on the implication of Mr. Ellis's figure of $1 \frac{1}{2}$ for programming/machine cost, pointed out that $\mathrm{Mr}$. Strachey's strictures were, to a large extent, unjust. The ideas of function languages were well known in Great Britain and much work has been done in them. The branched chain têchnique had been in use at
Birkbeck College for at least three years and was described in several papers so that a claim that "no one in Britain had experience of it" was patently false. So far as lack of large, random-access, stores on British machines was concerned, Dr. Booth maintained that far from being due to lack of imagination, the situation was actually caused by lack of Government support for British machines.

A vigorous discussion, in which the topics ranged from qualifications and training of programmers to the various kinds of 'meta-language' in machine translation, ended the session.
A. D. Воотн

\title{
PHILOSOPHICAL TRANSACTIONS OF THE ROYAL SOCIETY
}

\author{
By DR. W. P. D. WIGHTMAN
}

Department of History and Philosophy of Science, King's College, University of Aberdeen

T HE spate of publications relating to the Royal Society of London during the past two years seems to have increased rather than diminished the already existing misunderstanding of the relation between the Society and the famous periodical which it encouraged, but for which on several occasions the Society published or caused to be published disclaimers for any responsibility. Recently, references have been made to volumes of the Philosophical Transactions of the Royal Society (sometimes with 'of London' added) in the seventeenth century, when no periodical with this title existed; statements have been made (or implied) that there was only one (or no) interruption in its publication; and, worst of all, that it was the 'official' journal of the Royal Society. The precise title would perhaps not be of any serious import but for the fact that the inclusion of the words 'of the Royal Society' suggests that it was a record of the 'Transactions' of that body and hence gives plausibility to the term 'official'. Since statements about the Philosophical Transactions (a few incorrect, and others by condensation definitely misleading) are scattered about over a large number of recent articles, it seemed desirable to assemble a sufficient number of 'advertisements' by the Society or its officers to establish the facts relating to the Philosophical Transactions. The purpose of this article is thus primarily bibliographical in the broad sense: it is not concerned with the purpose or quality of the Transactions. It is basod on an examination (though, of course, far from exhaustive) of every volume of the Transactions (and Philosophical Collections to be referred to below) in the first two centuries of its existence.

The title on the first number issued and on the title page of every subsequent volume until Vol. 66 of 1776 was: "Philosophical Transactions: giving some accompt of the present undertakings, studies, and labours of the Ingenious in many considerable parts of the world".

There is no mention of the Royal Society other than in the imprint of its printers, John Martyn and James Allestry, and in Oldenburg's dedicatory epistle. Moreover, there is a clear indication that the editor and publisher had cast his net widely to get a representative review: the result was in fact a great deal more like Nature than a mere organ of publication of individual researches. But, despite this clear indication, confusion must have arisen at so early a date as to require the following disclaimer to be published in No. 12 of May 1666: "Whereas 'tis taken notice of that several persons perswade them. selves that these Philosophical Transactions are publish't by the Royal Society, notwithstanding many circumstances to be met with in the already publish't ones that import the contrary: the Writer thereof hath thought fit, expressly here to declare that that perswasion, if there be any such indeed, is a mere mistake. . . . Though he denios not, but that having the honour and advantage of being a Fellow of the said Society, he inserts at times some of the Particulars that are presented to them".

The last number of the Transactions in the first run was dated February 1679 . From some time in the same year (colophon of first number) to April 1682 their place was taken by Robert Hooke's Philosophical Collections "containing an account of such physical, anatomical, ... or other mathematical and philosophical experiments and observations as have lately come to the publisher's hands. As also an account of some books of this kind lately published". A similar 'advertisement' was printed in the number of December 1681. The Philosophical Transactions recommenced in January 1683 with the preface: "Although the writing of these Transactions is not to be looked upon as the Business of the Royal Society, yet in regard they are a Specimen of many things which lie before them. . . They have thought fit to take care for the revival thereof. . . ." Vol. 16 contained the numbers issued during 1686 and 1687 and bore the imprint "London 1688" (some previous volumes were printed at Oxford "at the [Sheldonian] Theater"). Thereafter, publication was suspended until early in 1691 "chiefly by reason that the unsettled posture of publick affairs did divert the thoughts of the curious towards matters of more immediate concern than are physical and mathematical enquiries. . .." These were, of course, the years of the 'Glorious Revolution', and this gap in the Transactions has been overlooked in some accounts.

It is not possible, nor indeed necessery, to cite every declaration of editorial policy : all call the same tune with variations $\rightarrow$ review of what is going on in the world of 'philosophy', including "an exact account of such experiments as having been made before the 
illustrious Royal Society... they shall be pleased to order or permit the publication of" (Halley, 1714).

Then in the Volume 47 (London 1753, but as usual containing the numbers issued during the years 1751 and 1752) came the announcement of a fundamental change: "The Committee appointed by the Royal Society to direct the publication of the Philosophical Transactions, take this opportunity to acquaint the public, that it fully appears, as well from the Councilbooks and journals of the Society as from the repeated declarations which have been made in several former Transactions, that the printing of them was always, from time to time, the single act of the respective Secreteries, till this present XLVII volume. And this information was thought the more necessary, not only as it has been the common opinion, that they were published by the authority, and under the direction, of the Society itself; but also, because several authors, both at home and abroad, have in their writings called them the Transactions of the Royal Society [italic in original]. . . .

"But the Society being of late years greatly inlarged ... it was thought adviseable that a Committee of their Members should be appointed to reconsider the papers read before them, and select out of them such, as they should judge most proper for publication in the future Transactions, which was accordingly done upon the 26 of March 1752."

In 1752, then, for the first time the Philosophical Transactions were in fact, but not yet in name, "of the Royal Society": the old, and by then quite unsuitable, title was retained until Vol. 66, dated 1776.

That the announcement of this change of policy was not a mere formality is shown by reference to the Council minutes for January and February 1752, when a number of 'questions' put by Lord Maccles. field (not yet president) were considered. The only one relevant to our purpose was whether there was any evidence of "intermeddling" by the Society with the Transactions, to decide which Thomas Birch, secretary, was requested to take the relevant literature home and examine it. Within a week he had made a sufficient investigation to satisfy the Council, and the changes were made as already described.

It remains only to add that the announcement made in 1752 appeared regularly for the next 123 years: it appeared for the last time in 1875 , by which time it was no longer true that "in late years" the Society had been "greatly inlarged"; it had, on the contrary, in pursuance of the 'reforms' of 1847 , been greatly reduced.

\section{DEOXYRIBONUCLEIC ACID: STRUCTURE, SYNTHESIS AND FUNCTION}

\begin{abstract}
THE eleventh Annual Reunion of the Société de Chimie Physique was held at the Col de Voza during June 26-30 and was devoted to papers and discussions on the structure, synthesis and function of deoxyribonucleic acid. (DNA). There were some thirty contributors to the symposium and the total number of participants was about 100 . The full texts of the contributions, including the discussions, are to be published in the October and November issues of Journal de Chimie Physique and will be republished afterwards in the form of a book.

The papers were divided into groups according to their subject-matter and the meeting commenced with a session on "Macromolecular Structure of DNA". Ch. Sadron (Strasbourg) presented results pointing to the existence of sub-units in DNA particles in solution and this was followed by a paper from $\mathrm{C}$. Levinthal (Cambridge, Mass.) on the hydrodynamic shear degradation of $T 2$ bacteriophage DNA in solution. This degradation of DNA can be brought about by normal laboratory procedures, and this had led to the conclusion that the molecular weight of DNA in cells is probably very much greater than the 6-10 million usually quoted and might be as much as 100 million. M. H. F. Wilkins (London) presented new data on the $A, B$ and $C$ configurations of DNA and evidence against the existence of base pairing other than that of Watson and Crick. In addition, the structure of denatured DNA and the relation of such structures to RNA was discussed. X-ray diffraction studies on DNA in solution were reported by V. Luzzati (Strasbourg), who concluded that the form and molecular weight of DNA were the same in dilute solution and in gels.
\end{abstract}

The second session dealt with "Electronic Aspects of Nucleic Acid Structure" and started with a paper by B. Pullman (Paris), who dealt with the electronic structure of nucleic acid constituents and the influence of this on the chemical and physico-chemical properties of DNA. This was followed by a paper from M. Kasha (Tallahassee), who was concerned with $n \rightarrow \pi^{*}$ optical transitions in polynucleotides, the exciton splitting phenomenon in hydrogen-bonded $N$-heterocyclic base pairs, and energy transfer and hypochromism in polynucleotides. L. A. Blumenfeld (Moscow), who unfortunately was not present, submitted an abstract on the magnetic and dielectric properties of DNA, and P. Douzou (Paris) presented results of experiments on the excitation and emission spectra of purine and pyrimidine bases, the corresponding mononucleotides, polyadenylic acid, DNA and nucleoproteins.

The third session was entitled "Chemical Sequence and Heterogeneity", and commenced with a presentation by B. Horecker (New York) of some recent results of Hurwitz and his collaborators on the DNA-requiring system for polyribonucleotide biosynthesis. In this system, the base composition of the newly formed polyribonucleotide appears to be determined by that of the DNA primer. J. Marmur (Brandeis University) described in some detail work on strand separation in DNA, on the recombination of strands and on the formation of hybrid chains. A system capable of the non-enzymic synthesis of polydeoxyribonucleotides from mono- and oligo-nucleotides present in deoxyribonuclease digests of DNA was described by A. Bendich (New York).

"Enzymic Synthesis of DNA" was the title of the fourth session, which was opened by a paper from R. M. S. Smellie (Glasgow) on the properties and intracellular location of the DNA polymerase in certain mammalian systems and on some possible mechan- 